\title{
Comparison between selected hormone and protein levels in serum and prostate tissue homogenates in men with benign prostatic hyperplasia and metabolic disorders
}

This article was published in the following Dove Press journal:

Clinical Interventions in Aging

\author{
Katarzyna Grzesiak,' \\ Aleksandra Rył, ${ }^{2}$ Irena \\ Baranowska-Bosiacka, ${ }^{3}$ \\ Iwona Rotter, ${ }^{2}$ Barbara \\ Dołęgowska, ${ }^{4}$ Marcin \\ Słojewski, ${ }^{5}$ Olimpia Sipak- \\ Szmigiel, ${ }^{6}$ Weronika \\ Ratajczak, ' Anna Lubkowska, ${ }^{7}$ \\ Emilia Metryka, ${ }^{3}$ Małgorzata \\ Piasecka,' Maria Laszczyńska' \\ 'Department of Histology and \\ Developmental Biology, Pomeranian \\ Medical University, Szczecin, Poland; \\ ${ }^{2}$ Department of Medical Rehabilitation \\ and Clinical Physiotherapy, Pomeranian \\ Medical University, Szczecin, Poland; \\ ${ }^{3}$ Department of Biochemistry and \\ Medical Chemistry, Pomeranian \\ Medical University, Szczecin, Poland; \\ ${ }^{4}$ Department of Laboratory Medicine, \\ Pomeranian Medical University, Szczecin, \\ Poland; ${ }^{5}$ Department of Urology and \\ Urological Oncology, Pomeranian \\ Medical University, Szczecin, Poland; \\ ${ }^{6}$ Department of Obstetrics and \\ Pathology of Pregnancy, Pomeranian \\ Medical University, Szczecin, Poland; \\ ${ }^{7}$ Department of Functional Diagnostics \\ and Physical Medicine, Pomeranian \\ Medical University, Szczecin, Poland
}

Correspondence: Aleksandra Rył

Department of Medical Rehabilitation and

Clinical Physiotherapy, Pomeranian Medical

University, Żołnierska 54, Szczecin 7I-210,

Poland

Tel +48 91 4800914

Email aleksandra.ryl@pum.edu.pl
Purpose: The purpose of the study was to assess the relationship between changes in the levels of selected hormones in serum and prostate tissue homogenate in regard to metabolic disorders in patients with diagnosed, surgically treated benign prostatic hyperplasia (BPH).

Patients and methods: The study involved a group of 154 men with a diagnosis of BPH with metabolic syndrome (MetS) and without MetS. The serum levels of the hormones - total testosterone, free testosterone, insulin, dehydroepiandrosterone sulfate, estradiol, luteinizing hormone, sex hormone binding globulin (SHBG), and insulin-like growth factor-1 (IGF-1) were determined using the ELISA method. Prostate tissue sections obtained from the patients during transurethral resection of the prostate were frozen in liquid nitrogen. We determined the levels of the same hormones.

Results: There was a statistically significant difference between the groups in terms of serum SHBG levels, but not in the prostate tissue SHBG levels. A similar relationship was observed in regard to IGF-1, the serum levels of which were significantly higher in patients with MetS. MetS had an effect on the ratio of hormone levels in serum to their levels in the prostate tissue. Correlations between the levels of biochemical parameters and the levels of hormones in serum and the prostate tissue of BPH patients with and without MetS demonstrate that serum SHBG levels correlated weakly with waist size and triglyceride levels.

Conclusion: The occurrence of MetS in BPH patients was associated with changes in the levels of hormones and proteins. These changes, however, were not always equivalent to changes in the levels of these parameters in prostate tissue. It should also be mentioned that MetS in BPH patients had an influence on a quantitative balance between the levels of SHBG in serum and prostate tissue.

Keywords: benign prostatic hyperplasia, hormone levels, metabolic disorders

\section{Introduction}

Benign prostatic hyperplasia (BPH) and metabolic disorders are important contributors to the health-related quality of life of aging men. ${ }^{1}$ The clinical manifestations of BPH generally involve lower urinary tract symptoms (LUTS), benign prostatic enlargement, and bladder outlet obstruction (BOO). ${ }^{2,3}$ The profile of research in the field of $\mathrm{BPH}$ etiology is complex: many studies have concerned the role of sex hormones - including sex hormone binding globulin (SHBG) and insulin-like growth factor (IGF) - in the development and progress of this disease..$^{4-7}$ Nevertheless, the findings reported so far are not consistent, and some studies have failed to demonstrate these relationships. ${ }^{8-10}$ 
Many studies have dealt with the association between BPH and metabolic syndrome (MetS). This connection may result from the fact that changes in hormone levels and metabolic disorders predispose to BPH. ${ }^{11-15}$ At the same time, there are a few publications that have compared sex hormone levels in serum and prostate tissue between men with BPH and those without it ${ }^{16,17}$ and there have been no studies comparing sex hormone levels in serum and prostate tissue homogenate in $\mathrm{BPH}$ patients in regard to concomitant MetS. Comparative studies of sex hormone levels in serum and prostate tissue have provided divergent results. ${ }^{17,18}$ In analyzing the potential contributors to BPH, it seems important to take into account the connection between the levels of selected sex hormones (determined in both serum and prostate tissue) and MetS. The lack of systematized knowledge of these issues can lead to a false assessment of the patient's clinical status. These discrepancies in the data most probably arise from different methods of sampling and analysis. ${ }^{17,18}$ It is thus reasonable to determine the levels of hormones involved in the etiopathology of BPH in serum and prostate tissue.

The purpose of this study was to assess the relationship between changes in the levels of selected hormones in serum and prostate tissue homogenate in regard to metabolic disorders in patients with diagnosed, surgically treated BPH.

\section{Patients and methods}

\section{Patients}

The study involved a group of 154 men with a diagnosis of BPH, aged 52-75 years (average: 66.96), who had undergone transurethral resection of the prostate. The patients were divided into two groups: group I consisted of 53 men with MetS, while group II comprised 101 men without MetS.

The men included in the study were patients at the Clinic of Urology and Urological Oncology, Pomeranian Medical University, Szczecin, Poland. The criteria for exclusion from the study were cancerous disease, active alcoholic disease, and thyroid conditions. The participants were treated with 5-alpha reductase inhibitors (orally, $5 \mathrm{mg}$ daily). The study was approved by the Bioethical Commission of the Pomeranian Medical University in Szczecin (approval number KB-0012/123/14). All participants gave their conscious written consent to take part in the study.

\section{Clinical examination}

Anthropometric parameters (weight, height, age, and waist size) were measured for all patients. The participants were asked to complete a questionnaire concerning their demographic details and chronic diseases. The men were divided into two groups: those with and without MetS, diagnosed on the basis of the International Diabetes Federation 2005 criteria. ${ }^{19}$ The patients were included in the MetS group if they had abdominal obesity $\geq 94 \mathrm{~cm}$ and at least two of the following abnormalities: triglyceride (TG) $\geq 150 \mathrm{mg} / \mathrm{dL}$ or treatment for dyslipidemia; high density lipoprotein (HDL) cholesterol $<40 \mathrm{mg} / \mathrm{dL}$ or treatment for dyslipidemia; blood pressure $\geq 130 / 85 \mathrm{mmHg}$ or treatment for hypertension; fasting plasma glucose $(\mathrm{FPG}) \geq 100 \mathrm{mg} / \mathrm{dL}$ or treatment for type- 2 diabetes. The body mass index (BMI) was calculated; overweight was diagnosed for BMI between 25 and $29.99 \mathrm{~kg} / \mathrm{m}^{2}$, and obesity for BMI $\geq 30 \mathrm{~kg} / \mathrm{m}^{2}$. For nondiabetic patients, we also calculated the insulin resistance index according to the following formula: fasting glucose $(\mathrm{mmol} / \mathrm{L})$ $\times$ fasting insulin $(\mu \mathrm{U} / \mathrm{mL}) / 22.5 .^{20}$ The ratios of the hormone levels in serum to the hormone levels in prostate tissue homogenate were calculated.

\section{Blood serum analysis}

Nine milliliters blood samples were taken for laboratory analysis from a cubital vein on an empty stomach between $7.30 \mathrm{am}$ and $9.00 \mathrm{am}$. The blood was collected using tubes with gel separator and clot activator. It was then centrifuged. Serum levels of insulin, FPG, total cholesterol, low density lipoprotein, HDL, and TG were determined using a spectrophotometric method with commercial reagent kits (Biolabo; Aqua-Med, Łódź, Poland).

The serum levels of the selected hormones - total testosterone (TT), free testosterone (FT), insulin, dehydroepiandrosterone sulfate (DHEAS), estradiol (E2), luteinizing hormone (LH), and SHBG - were determined using the ELISA method with commercial reagent kits (DRG International, Marburg, Germany).

\section{Analysis of protein and hormone levels in prostate homogenates}

Prostate tissue sections obtained from the patients during transurethral resection of the prostate were immediately frozen in liquid nitrogen. Small tissue sections were macerated in a metal homogenizer cooled with liquid nitrogen. Thus, prepared, powdered, and frozen prostate tissues, in a quantity equivalent to several milligrams of protein, were placed in tubes with $500 \mathrm{~mL} 0.9 \% \mathrm{NaCl}$ (previously cooled to $4^{\circ} \mathrm{C}$ ) using a cooled teaspoon, and then vortexed. Next, the tissues were homogenized using a knife homogenizer for about 15 seconds. The homogenates were centrifuged at $14,000 \mathrm{~g}$ at $4^{\circ} \mathrm{C}$. We determined the levels of TT, FT, insulin, 
DHEAS, E2, LH, and SHBG in the resulting supernatants. The hormones and proteins were analyzed using commercial reagent kits (DRG International). The results were shown as units per $1 \mathrm{~g}$ of protein.

\section{Statistical analysis}

Statistical analysis was performed using SPSS Statistics 17.0 software. The study sample was described by means of basic statistics (mean, SD, minimum, and maximum values). The normality of the distribution was assessed using the ShapiroWilk test. Differences between groups were determined by the Mann-Whitney $U$-test and Student's $t$-test. Pearson's correlation coefficient was applied. The level of significance was set at $p \leq 0.05$.

\section{Results}

The study involved 154 men, 47 of whom were taking statins, 36 had been diagnosed with and were being treated for type 2 diabetes, and 97 were receiving treatment for hypertension.

The results of a comparison between the hormone levels in serum and prostate tissue of BPH patients are shown in Table 1. The data suggest significant differences in all tested parameters between serum and prostate tissue homogenates.

Table 2 shows the results of a comparison between selected hormone levels in serum and prostate tissue in patients with and without MetS. There was a statistically significant difference between the groups in terms of serum SHBG levels $(p=0.015)$, but not in the prostate tissue SHBG levels $(p=0.106)$. A similar relationship was observed in regard to IGF-1, the serum levels of which were significantly higher in patients with MetS $(p=0.017)$. Table 3 shows the results for the ratio of selected hormone levels in serum and prostate tissue of BPH patients with and without MetS. MetS had an effect on the ratio of hormone levels in serum to their levels in the prostate tissue. The patients with MetS had significantly lower ratios of E2 $(p=0.069)$ to SHBG $(p=0.025)$.

Pearson's correlations between the levels of biochemical parameters and the levels of hormones in serum and the prostate tissue of $\mathrm{BPH}$ patients with and without MetS (Table 4) demonstrated that serum SHBG levels correlated weakly with waist size $(p=-0.202, p=0.012)$ and $\mathrm{TG}$ levels $(p=-0.217, p=0.007)$. No such relationships were found for prostate tissue. Instead, we observed correlations between the level of TT and the levels of SHBG $(p=-0.187$, $p=0.032)$ and FT $(p=0.201, p=0.012)$. Serum LH levels correlated with patients' age $(p=0.167, p=0.040)$ and FPG $(p=0.299, p=0.001)$. The level of FPG correlated with the levels of LH $(p=0.299, p=0.001)$ and TT $(p=-0.160, p=$ $0.047)$, but only in serum. Serum insulin levels correlated positively with waist size $(p=0.199, p=0.026)$, BMI $(p=$ $0.243, p=0.006)$, age $(p=0.292, p=0.001), \mathrm{TG}(p=0.209$, $p=0.019)$, and FPG $(p=0.214, p=0.016)$.

\section{Discussion}

The relationships between metabolic disorders and the concentrations of hormones involved in the etiopathogenesis of $\mathrm{BPH}$ are a focus of ongoing research. What has been observed during the process of men's aging is a physiological decline in the level of testosterone, resulting from the decreased synthesis of androgen hormones. ${ }^{5,21}$ This can lead to many clinical symptoms, such as a loss of libido, reduced muscle strength and muscle mass, decreased bone mineralization, and decreased testicular volume. ${ }^{21}$ Nonetheless, the role of the decline in testosterone levels, which is found in $\mathrm{BPH}$ alongside metabolic disorders, is open to debate. Testosterone and the product of its enzymatic conversion - dihydrotestosterone (DHT) - are known to take part in the growth and proliferation of prostate cells. ${ }^{22,23}$

Table I Comparison between serum and prostate tissue levels of hormones and proteins in BPH patients

\begin{tabular}{|c|c|c|c|c|c|c|c|c|c|}
\hline \multirow[t]{2}{*}{ Parameters } & \multicolumn{4}{|c|}{ Serum concentration } & \multirow[t]{2}{*}{ Parameters } & \multicolumn{4}{|c|}{ Concentration in prostate tissue } \\
\hline & $\overline{\mathbf{x}}$ & SD & Min & Max & & $\overline{\overline{\mathbf{x}}}$ & SD & Min & Max \\
\hline DHEAS $(\mu \mathrm{g} / \mathrm{mL})$ & 0.58 & 0.99 & 0.002 & 7.89 & DHEAS (pg/mg protein) & 5.04 & 3.06 & 0.81 & 15.94 \\
\hline $\mathrm{E} 2(\mathrm{pg} / \mathrm{mL})$ & 48.48 & 26.36 & 11.00 & 176.03 & E2 (pg/mg protein) & 0.02 & 0.01 & 0.00 & 0.06 \\
\hline SHBG (nmol/L) & 44.15 & 17.33 & 8.19 & 107.37 & SHBG (pmol/mg protein) & 0.02 & 0.01 & 0.01 & 0.05 \\
\hline $\mathrm{LH}(\mathrm{mlU} / \mathrm{mL})$ & 8.17 & 5.70 & 0.90 & 38.53 & LH (mlU/mg protein) & 0.14 & 0.08 & 0.02 & 0.42 \\
\hline TT (ng/mL) & 4.30 & 2.03 & 0.71 & 11.15 & TT (pg/mg protein) & 13.99 & 12.85 & 1.86 & 64.17 \\
\hline $\mathrm{TF}(\mathrm{pg} / \mathrm{mL})$ & 7.49 & 6.71 & 0.08 & 48.62 & TF (pg/mg protein) & 0.02 & 0.02 & 0.0002 & 0.12 \\
\hline IGF-I (ng/mL) & 85.75 & 36.18 & 33.81 & 361.90 & IGF-I (ng/mg protein) & 0.36 & 0.24 & 0.02 & 1.309 \\
\hline $\mathrm{I}(\mu \mathrm{IU} / \mathrm{mL})$ & 15.83 & 12.86 & 0.10 & 62.88 & I ( $\mu \mathrm{g} / \mathrm{mg}$ protein) & $7.20 \times 10^{-5}$ & $4.40 \times 10^{-5}$ & $7.00 \times 10^{-6}$ & $3.14 \times 10^{-4}$ \\
\hline
\end{tabular}

Note: $\bar{X}$, arithmetic average (Mann-Whitney $U$-test and Student's $t$-test).

Abbreviations: BPH, benign prostatic hyperplasia; SD, standard deviation; Min, minimum; Max, maximum; DHEAS, dehydroepiandrosterone sulfate; E2, estradiol; SHBG, sex hormone binding globulin; LH, luteinizing hormone; TT, total testosterone; TF, free testosterone; IGF-I, insulin-like growth factor-I; I, insulin. 
Table 2 Comparison between hormone levels in serum and prostate tissue homogenates in BPH patients with and without MetS

\begin{tabular}{|c|c|c|c|c|c|c|c|c|c|c|}
\hline \multicolumn{2}{|c|}{ Parameters } & \multicolumn{4}{|c|}{$\begin{array}{l}\text { Patients with BPH and with MetS } \\
(n=53)\end{array}$} & \multicolumn{4}{|c|}{$\begin{array}{l}\text { Patients with BPH and without MetS } \\
(n=10 I)\end{array}$} & \multirow{3}{*}{$\begin{array}{l}p \text {-value } \\
0.939 \\
\end{array}$} \\
\hline & & \multirow{2}{*}{$\begin{array}{l}\bar{x} \\
0.61 \\
\end{array}$} & \multirow{2}{*}{$\begin{array}{l}\text { SD } \\
0.80\end{array}$} & \multirow{2}{*}{$\begin{array}{l}\text { Min } \\
0.003\end{array}$} & \multirow{2}{*}{$\begin{array}{l}\text { Max } \\
7.89 \\
\end{array}$} & \multirow{2}{*}{$\begin{array}{l}\overline{\overline{\mathbf{X}}} \\
0.56\end{array}$} & \multirow{2}{*}{\begin{tabular}{|l|} 
SD \\
0.92 \\
\end{tabular}} & \multirow{2}{*}{$\begin{array}{l}\text { Min } \\
0.002 \\
\end{array}$} & \multirow{2}{*}{\begin{tabular}{|l|} 
Max \\
7.86 \\
\end{tabular}} & \\
\hline DHEAS & Serum $(\mu g / m L)$ & & & & & & & & & \\
\hline & Tissue (pg/mg protein) & 4.99 & 2.66 & 1.09 & 13.30 & 5.07 & 3.25 & 0.81 & 15.94 & 0.735 \\
\hline \multirow[t]{2}{*}{ E2 } & Serum $(\mathrm{pg} / \mathrm{mL})$ & 46.87 & 29.79 & 11.00 & 176.03 & 49.33 & 24.48 & 11.89 & 123.56 & 0.289 \\
\hline & Tissue (pg/mg protein) & $1.60 \times 10^{-2}$ & $1.20 \times 10^{-2}$ & $3.00 \times 10^{-3}$ & $5.60 \times 10^{-2}$ & $1.40 \times 10^{-2}$ & $9.00 \times 10^{-3}$ & $2.00 \times 10^{-3}$ & $4.90 \times 10^{-2}$ & 0.398 \\
\hline \multirow[t]{2}{*}{ SHBG } & Serum (nmol/L) & 40.51 & 15.37 & 8.19 & 107.37 & 46.07 & 17.29 & 11.93 & 103.52 & $0.016 *$ \\
\hline & Tissue (pmol/mg protein) & $2.50 \times 10^{-2}$ & $1.00 \times 10^{-2}$ & $1.10 \times 10^{-2}$ & $5.30 \times 10^{-2}$ & $2.20 \times 10^{-2}$ & $9.00 \times 10^{-2}$ & $1.00 \times 10^{-2}$ & $5.00 \times 10^{-2}$ & 0.106 \\
\hline \multirow[t]{2}{*}{$\mathrm{LH}$} & Serum $(\mathrm{mlU} / \mathrm{mL})$ & 7.26 & 4.86 & 1.11 & 27.18 & 8.65 & 6.06 & 0.90 & 38.53 & 0.181 \\
\hline & Tissue (mIU/mg protein) & 0.15 & 0.08 & 0.05 & 0.42 & 0.14 & 0.08 & 0.02 & 0.42 & 0.248 \\
\hline \multirow[t]{2}{*}{ TT } & Serum $(\mathrm{ng} / \mathrm{mL})$ & 4.15 & 2.12 & 1.23 & 11.15 & 4.38 & 1.99 & 0.71 & 10.24 & 0.279 \\
\hline & Tissue (pg/mg protein) & 14.06 & 12.97 & 2.32 & 53.31 & 13.96 & 12.86 & 1.86 & 64.17 & 0.855 \\
\hline \multirow[t]{2}{*}{$\mathrm{TF}$} & Serum $(\mathrm{pg} / \mathrm{mL})$ & 6.82 & 7.58 & 0.08 & 48.62 & 7.85 & 6.22 & 0.20 & 34.83 & 0.145 \\
\hline & Tissue (pg/mg protein) & $1.90 \times 10^{-2}$ & $1.90 \times 10^{-2}$ & $2.00 \times 10^{-3}$ & $8.70 \times 10^{-2}$ & $2.00 \times 10^{-2}$ & $2.30 \times 10^{-2}$ & $2.00 \times 10^{-3}$ & $1.16 \times 10^{-1}$ & 0.777 \\
\hline \multirow[t]{2}{*}{ IGF-I } & Serum (ng/mL) & 91.27 & 28.84 & 39.07 & 169.90 & 82.85 & 39.31 & 33.81 & 361.90 & $0.017^{*}$ \\
\hline & Tissue (ng/mg protein) & 0.36 & 0.28 & 0.04 & 1.31 & 0.36 & 0.22 & 0.02 & 1.19 & 0.608 \\
\hline \multirow[t]{2}{*}{ I } & Serum $(\mu \mathrm{IU} / \mathrm{mL})$ & 17.48 & 14.80 & 0.10 & 62.88 & 15.03 & 11.82 & 0.10 & 59.55 & 0.439 \\
\hline & Tissue (ug/mg protein) & $8.02 \times 10^{-5}$ & $5.32 \times 10^{-5}$ & $7.10 \times 10^{-6}$ & $3.14 \times 10^{-4}$ & $6.92 \times 10^{-5}$ & $4.09 \times 10^{-5}$ & $8.70 \times 10^{-6}$ & $1.86 \times 10^{-4}$ & 0.142 \\
\hline
\end{tabular}

Note: $p$, statistical significance; $\bar{X}$, arithmetic average; *statistically significant parameter (Mann-Whitney U-test and Student's t-test).

Abbreviations: BPH, benign prostatic hyperplasia; MetS, metabolic syndrome; SD, standard deviation; Min, minimum; Max, maximum; DHEAS, dehydroepiandrosterone sulfate; E2, estradiol; SHBG, sex hormone binding globulin; LH, luteinizing hormone; TT, total testosterone; TF, free testosterone; IGF-I, insulin-like growth factor-I; I, insulin.

In our study, the levels of all the parameters in BPH patients differed significantly between the prostate tissue and serum. The literature lacks accurate data on testosterone and DHT levels in prostate tissue homogenates, in part due to differing methods of collecting material for chemical analysis. At present, DHT levels in prostate tissue are believed to be independent of BPH. At the same time, there are no adequate data on testosterone levels in prostate tissue. ${ }^{18,24,25}$

Results regarding particular hormone levels can slightly differ depending on the prostate tissue sampling method.
Tissues obtained via transurethral resection of the prostate may undergo electrothermal damage. Tissues obtained by biopsy can only be preserved for a short time. This method, however, enables accurate collection of the material from particular areas of the prostate. Tissues taken during open surgery or autopsy are dehydrated and degenerated. ${ }^{18}$

Pejčić et $\mathrm{al}^{17}$ reported median TT and DHT levels that were akin to those in our analysis and the literature data. However, these results cannot be objectively compared owing to the differing ways of collecting research material

Table 3 Comparison between the ratios of hormone levels in serum to their levels in prostate tissue homogenates in BPH patients with and without MetS

\begin{tabular}{|c|c|c|c|c|c|c|c|c|c|c|}
\hline \multicolumn{2}{|c|}{ Parameters } & \multicolumn{4}{|c|}{$\begin{array}{l}\text { Patients with BPH and with MetS } \\
(n=53)\end{array}$} & \multicolumn{4}{|c|}{$\begin{array}{l}\text { Patients with BPH and without MetS } \\
(n=10 I)\end{array}$} & \multirow[t]{2}{*}{$p$-value } \\
\hline & & $\overline{\overline{\mathbf{X}}}$ & SD & Min & Max & $\overline{\overline{\mathbf{X}}}$ & SD & Min & Max & \\
\hline \multirow{8}{*}{ 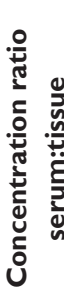 } & DHEAS & 0.97 & 0.88 & 0.003 & 3.08 & 0.59 & 0.40 & 0.002 & 2.95 & 0.906 \\
\hline & E2 & $4.12 \times 10^{3}$ & $4.90 \times 10^{3}$ & $5.09 \times 10^{2}$ & $3.13 \times 10^{4}$ & $4.68 \times 10^{3}$ & $4.16 \times 10^{3}$ & $7.85 \times 10^{2}$ & $2.53 \times 10^{4}$ & 0.050 \\
\hline & SHBG & I,928.59 & $9,303.96$ & $3,875.12$ & $4,813.72$ & $2,529.23$ & $\mathrm{I}, 386.28$ & $3,529.62$ & $6,605.10$ & $0.025^{*}$ \\
\hline & $\mathrm{LH}$ & 69.44 & 68.34 & 6.90 & 380.29 & 87.18 & 77.11 & 5.61 & 480.62 & 0.096 \\
\hline & TT & 0.49 & 0.40 & 0.06 & 2.25 & 0.56 & 0.35 & 0.02 & 3.02 & 0.981 \\
\hline & $\mathrm{TF}$ & 613.57 & 643.44 & 13.30 & 2,769.7I & 791.02 & 907.02 & 6.85 & $5,456.04$ & 0.452 \\
\hline & IGF-I & 440.70 & 436.72 & 55.82 & $2,357.10$ & 395.38 & 730.49 & 64.64 & $6,621.70$ & 0.202 \\
\hline & I & $4.69 \times 10^{5}$ & $1.37 \times 10^{6}$ & $3.18 \times 10^{2}$ & $8.85 \times 10^{6}$ & $2.89 \times 10^{5}$ & $2.78 \times 10^{5}$ & $1.30 \times 10^{3}$ & $1.29 \times 10^{6}$ & 0.734 \\
\hline
\end{tabular}

Note: $p$, statistical significance; $\bar{X}$, arithmetic average; *statistically significant parameter (Mann-Whitney U-test and Student's $t$-test).

Abbreviations: BPH, benign prostatic hyperplasia; MetS, metabolic syndrome; SD, standard deviation; Min, minimum; Max, maximum; DHEAS, dehydroepiandrosterone sulfate; E2, estradiol; SHBG, sex hormone binding globulin; LH, luteinizing hormone; TT, total testosterone; TF, free testosterone; IGF-I, insulin-like growth factor-I; I, insulin. 
Table 4 Analysis of Pearson's correlations between the levels of biochemical parameters and hormones in serum and prostate tissue homogenates in BPH patients

\begin{tabular}{|c|c|c|c|c|c|c|c|c|c|c|}
\hline \multicolumn{3}{|c|}{ Parameters } & Age & BMI & WC & TG & TC & HDL & LDL & FPG \\
\hline \multirow[t]{4}{*}{ DHEAS } & \multirow[t]{2}{*}{ Serum } & $R$ & -0.030 & -0.116 & -0.014 & 0.089 & 0.114 & -0.056 & 0.108 & 0.078 \\
\hline & & $p$ & 0.717 & 0.152 & 0.861 & 0.271 & 0.161 & 0.491 & 0.187 & 0.338 \\
\hline & \multirow[t]{2}{*}{ Tissue } & $R$ & -0.017 & 0.011 & 0.112 & 0.063 & -0.036 & -0.138 & -0.020 & 0.139 \\
\hline & & $p$ & 0.844 & 0.901 & 0.203 & 0.472 & 0.679 & 0.115 & 0.823 & 0.111 \\
\hline \multirow[t]{4}{*}{ E2 } & \multirow[t]{2}{*}{ Serum } & $R$ & -0.071 & 0.014 & 0.066 & -0.005 & -0.077 & 0.040 & -0.096 & -0.048 \\
\hline & & $p$ & 0.384 & 0.868 & 0.417 & 0.954 & 0.341 & 0.620 & 0.242 & 0.557 \\
\hline & \multirow[t]{2}{*}{ Tissue } & $R$ & 0.003 & 0.114 & $0.198^{*}$ & 0.043 & -0.048 & -0.106 & -0.022 & 0.088 \\
\hline & & $p$ & 0.975 & 0.195 & 0.023 & 0.626 & 0.584 & 0.226 & 0.805 & 0.318 \\
\hline \multirow[t]{4}{*}{ SHBG } & \multirow[t]{2}{*}{ Serum } & $R$ & 0.090 & -0.150 & -0.202 & -0.217 & 0.065 & 0.116 & 0.120 & -0.109 \\
\hline & & $p$ & 0.267 & 0.065 & $0.012^{*}$ & $0.007^{*}$ & 0.425 & 0.153 & 0.141 & 0.177 \\
\hline & \multirow[t]{2}{*}{ Tissue } & $R$ & -0.059 & 0.098 & 0.002 & -0.079 & -0.187 & -0.128 & -0.124 & 0.099 \\
\hline & & $p$ & 0.505 & 0.265 & 0.979 & 0.371 & $0.032^{*}$ & 0.144 & 0.163 & 0.261 \\
\hline \multirow[t]{4}{*}{ LH } & \multirow[t]{2}{*}{ Serum } & $R$ & 0.167 & 0.103 & -0.053 & -0.089 & -0.109 & 0.029 & -0.109 & 0.299 \\
\hline & & $p$ & $0.040 *$ & 0.204 & 0.517 & 0.270 & 0.177 & 0.717 & 0.181 & $0.001 *$ \\
\hline & \multirow[t]{2}{*}{ Tissue } & $R$ & -0.025 & 0.128 & -0.118 & -0.127 & -0.110 & -0.103 & -0.029 & 0.149 \\
\hline & & $p$ & 0.790 & 0.176 & 0.212 & 0.176 & 0.241 & 0.272 & 0.758 & 0.112 \\
\hline \multirow[t]{4}{*}{ TT } & \multirow[t]{2}{*}{ Serum } & $R$ & -0.024 & -0.103 & -0.048 & -0.062 & 0.113 & 0.128 & 0.106 & -0.160 \\
\hline & & $p$ & 0.772 & 0.204 & 0.556 & 0.448 & 0.164 & 0.113 & 0.195 & $0.047^{*}$ \\
\hline & \multirow[t]{2}{*}{ Tissue } & $R$ & -0.010 & 0.002 & -0.079 & -0.053 & -0.091 & -0.065 & -0.037 & -0.032 \\
\hline & & $p$ & 0.910 & 0.980 & 0.372 & 0.545 & 0.298 & 0.456 & 0.675 & 0.716 \\
\hline \multirow[t]{4}{*}{$\mathrm{TF}$} & \multirow[t]{2}{*}{ Serum } & $R$ & -0.071 & -0.097 & -0.011 & 0.148 & 0.201 & 0.026 & 0.131 & -0.026 \\
\hline & & $p$ & 0.386 & 0.234 & 0.892 & 0.067 & $0.012^{*}$ & 0.750 & 0.109 & 0.750 \\
\hline & \multirow[t]{2}{*}{ Tissue } & $R$ & -0.026 & -0.014 & -0.087 & 0.001 & -0.081 & -0.102 & -0.033 & 0.004 \\
\hline & & $p$ & 0.774 & 0.873 & 0.333 & 0.992 & 0.366 & 0.254 & 0.716 & 0.963 \\
\hline \multirow[t]{4}{*}{ IGF-I } & \multirow[t]{2}{*}{ Serum } & $R$ & -0.017 & 0.027 & 0.047 & 0.046 & 0.102 & 0.004 & 0.095 & -0.026 \\
\hline & & $P$ & 0.831 & 0.736 & 0.566 & 0.571 & 0.210 & 0.964 & 0.244 & 0.752 \\
\hline & \multirow[t]{2}{*}{ Tissue } & $R$ & -0.089 & 0.074 & -0.013 & -0.030 & -0.107 & -0.107 & -0.051 & -0.011 \\
\hline & & $p$ & 0.325 & 0.416 & 0.888 & 0.744 & 0.237 & 0.237 & 0.579 & 0.903 \\
\hline \multirow[t]{4}{*}{ I } & \multirow[t]{2}{*}{ Serum } & $R$ & 0.292 & 0.243 & 0.199 & 0.209 & 0.044 & -0.068 & -0.003 & 0.214 \\
\hline & & $p$ & $0.001 *$ & $0.006 *$ & $0.026 *$ & $0.019 *$ & 0.623 & 0.451 & 0.973 & $0.016 *$ \\
\hline & \multirow[t]{2}{*}{ Tissue } & $R$ & -0.029 & 0.008 & 0.110 & 0.076 & 0.117 & -0.094 & 0.145 & 0.110 \\
\hline & & $p$ & 0.752 & 0.935 & 0.231 & 0.410 & 0.203 & 0.303 & 0.114 & 0.229 \\
\hline
\end{tabular}

Note: $p$, statistical significance; $R$, correlation coefficient; *statistically significant parameter (Pearson's correlations).

Abbreviations: BPH, benign prostatic hyperplasia; WC, waist circumference; BMI, body mass index; TG, triglyceride; TC, total cholesterol; HDL, high density lipoprotein; LDL, low density lipoprotein; FPG, fasting plasma glucose; DHEAS, dehydroepiandrosterone sulfate; E2, estradiol; SHBG, sex hormone binding globulin; LH, luteinizing hormone; TT, total testosterone; TF, free testosterone; IGF-I, insulin-like growth factor-I; I, insulin.

(biopsy in Pejčić et al's study) and the different methods (liquid chromatography-mass spectrometry [LC-MS] and liquid chromatography-tandem mass spectrometry [LC-MS/ MS]) of determining hormone levels in the tested material. The researchers demonstrated that both TT and DHT accumulated in hyperplastic prostate tissue, but that DHT levels were visibly higher. One additionally analyzed parameter in that study was prostate volume. The authors noted that the mean DHT-to-TT ratio in larger prostates was considerably higher than in smaller ones.
In our study, TT and DHEAS levels in prostate tissue homogenates were analyzed in patients both with and without MetS, but no statistically significant differences were revealed.

A similar investigation was conducted by Parsons ${ }^{26}$ as a part of a large cohort study, the Baltimore Longitudinal Study of Aging. Parsons et al developed a model on the basis of which they found that a $1 \mathrm{~kg} / \mathrm{m}^{2}$ increase in BMI was accompanied by an increase in prostate volume of $0.41 \mathrm{~mL}$. They also observed that patients with BMI $\geq 35 \mathrm{~kg} / \mathrm{m}^{2}$, who 
according to WHO standards are patients with "2nd degree obesity", were at a 3.5 times greater risk of BPH than patients with normal weight (BMI $<25 \mathrm{~kg} / \mathrm{m}^{2}$ ). Another group of researchers ${ }^{27}$ performed a meta-analysis of 5,403 patients with prostatic hyperplasia from different countries. The subjects were again divided into a group with and a group without MetS, and the men with MetS proved to have notably greater prostate volumes. Of the parameters diagnosed in the etiology of MetS, only waist size and HDL levels were significantly predictive of BPH risk.

In our study, FPG levels correlated with the levels of LH and TT. This relationship was, however, only observed in serum. Furthermore, only serum insulin levels correlated positively with age, BMI, waist size, and FPG levels. Serum LH levels correlated with patients' age and FPG. Statistically significant differences were also noted in serum SHBG levels, depending on the presence of MetS. This association was not observed in the levels of this parameter in the prostate tissue homogenate. Comparison of the ratios of the hormones and protein levels in serum to their levels in the prostate tissue between patients with and without MetS revealed that men with MetS had statistically significant lower SHBG ratios. Pearson's correlation analysis demonstrated that serum SHBG levels weakly correlated with waist size and TG levels. There was no such relationship for prostate tissue. Correlations between the level of TT and the levels of SHBG and FT were observed in prostate tissue.

Lee et $\mathrm{al}^{28}$ suggested that the level of testosterone may be loosely related not only to enlargement of the prostate, but also to the occurrence of LUTS and erectile dysfunction. In a study $^{8}$ of over 2,000 men aged 40-59 years, BPH symptoms did not correlate with serum TT levels. A similar observation was made by Yassin et al, ${ }^{29}$ who found that men with MetS often had lower TT levels, which did not directly contribute to LUTS. These authors also claimed that hyperreactivity of the autonomic nervous system played an important part in the pathogenesis of LUTS, which may have been caused by disturbed TT levels. Kim et al also examined the correlations between the levels of testosterone, insulin, glucose, weight, and prostate volume in BPH patients subjected to transurethral resection of the prostate..$^{30}$ They informed that only the TT and insulin levels exerted no significant effects on prostate volume. A new look at these issues was provided by a study on the impact of testosterone supplementation on BPH treatment. ${ }^{31,32}$ Antunes et al ${ }^{33}$ carried out comparative research of the relationships between weight and TT levels in patients with LUTS. They asserted that, in a group of 725 obese men (mean age 65 years, $\mathrm{BMI} \geq 25 \mathrm{~kg} / \mathrm{m}^{2}$ ), age and TT levels were LUTS-related factors. Nevertheless, these authors did not find any associations between the parameters they tested and the levels of FT and SHBG. A similar analysis was performed by Kaplan et $\mathrm{al},{ }^{23}$ who noted a connection between obesity and low testosterone levels in men with BPH.

The role of estrogens in the regulation of the male reproductive system is quite well understood. ${ }^{34,35}$ In men, estrogens mainly arise through the process of peripheral aromatization of testosterone. ${ }^{34}$ With age, serum E2 levels either remain the same or rise, thus leading to an increase in the E2-to-TT ratio. ${ }^{35}$ In our study, patients with MetS had significantly lower ratios of serum to tissue E2 levels $(p=0.069)$. In the analysis of Bélanger et al, ${ }^{35} \mathrm{E} 2$ levels correlated with age in $\mathrm{BPH}$ patients with MetS, but not in those without it. Research on an animal model ${ }^{36}$ confirmed that changes in the E2-to-TT ratio contribute to gradual prostatic enlargement and urination disorders in rats. This study, however, did not support the hypothesis that changes in the ratio of these hormone levels were associated with LUTS and urinary obstruction. Sex hormone levels in a large group of aging men with a diagnosis of BPH were investigated by Tan et al, ${ }^{37}$ who reported that patients with prostatic hyperplasia had higher E2 levels than their counterparts without this condition.

IGF-1 is a mitogenic hormone synthesized mostly in the liver and locally in various types of tissues. There is a hypothesis that IGF-1, which is similar to insulin in structure, can bind to the same receptors and activate pathways involved in the growth and proliferation of prostate cells. Disturbed regulation of this factor and its overexpression may be a part of the etiology of both benign and malignant tissue hyperplasia. ${ }^{38}$

Ryl et a ${ }^{39}$ demonstrated that the level of IGF-1 in BPH patients without MetS correlated with the parameters of a lipid profile. They also found that the coexistence of MetS and BPH disturbed this correlation. The in vitro analysis of Siejka et $\mathrm{al}^{40}$ revealed that pharmacological inhibition of growth factor production can suppress proliferation of human BPH cells. Hyperinsulinemia stimulates the liver to produce increased amounts of IGF-1, which binds to insulin receptors, thus causing prostatic hyperplasia. ${ }^{41}$ What is more, it was demonstrated that stress-activated kinases in prostate stromal fibroblasts induce IGF-1 secretion, which stimulates prostate epithelial cell division through the activation of particular target genes. ${ }^{42}$ In our study, patients with MetS had significantly higher serum IGF-1 levels. The same relationship was not confirmed in their prostate tissue. However, what should be emphasized in the pathomechanism of BPH is its multifactor etiology, and especially complex hormonal regulation. The study that deserves particular attention is that 
of Gat et $\mathrm{al}^{43,44}$ who found that prostatic tissue is not directly affected by serum hormone levels, but instead gets a much higher level of testosterone straight from the testes before it is diluted by the overall circulation.

\section{Conclusion}

Our study focused on the levels of certain hormones in serum and prostate tissue in $\mathrm{BPH}$ patients additionally diagnosed with MetS. The occurrence of MetS in BPH patients was associated with changes in the levels of hormones and proteins (IGF-1 and SHBG). These changes, however, were not always equivalent to changes in the levels of these parameters in prostate tissue. It should also be mentioned that MetS in BPH patients had an influence on a quantitative balance between the levels of SHBG in serum and prostate tissue. Our results indicate the necessity for further research on the contribution of MetS to the development and clinical picture of BPH.

\section{Disclosure}

The authors report no conflicts of interest in this work.

\section{References}

1. Hatami H, Deihim T, Amiri P, Cheraghi L, Azizi F. Association between metabolic syndrome and health-related quality of life among individuals with normal and impaired glucose regulation: findings from Tehran lipid and glucose study. Arch Iran Med. 2016;19(8):577-583.

2. Abdollah F, Briganti A, Suardi N, et al. Metabolic syndrome and benign prostatic hyperplasia: evidence of a potential relationship, hypothesized etiology, and prevention. Korean J Urol. 2011;52(8):507-516.

3. Vignozzi L, Gacci M, Maggi M. Lower urinary tract symptoms, benign prostatic hyperplasia and metabolic syndrome. Nat Rev Urol. 2016;13(2):108-119.

4. Jarvis TR, Chughtai B, Kaplan SA. Testosterone and benign prostatic hyperplasia. Asian J Androl. 2015;17(2):212-216.

5. Nicholson TM, Ricke WA. Androgens and estrogens in benign prostatic hyperplasia: past, present and future. Differentiation. 2011; 82(4-5):184-199.

6. Favilla V, Cimino S, Castelli T, et al. Relationship between lower urinary tract symptoms and serum levels of sex hormones in men with symptomatic benign prostatic hyperplasia. BJU Int. 2010;106(11): 1700-1703.

7. Grosman H, Fabre B, Lopez M, et al. Complex relationship between sex hormones, insulin resistance and leptin in men with and without prostatic disease. Aging Male. 2016;19(1):40-45.

8. Lee JH, Kim Y, Park YW, Lee DG. Relationship between benign prostatic hyperplasia/lower urinary tract symptoms and total serum testosterone level in healthy middle-aged eugonadal men. $J$ Sex Med. 2014;11(5):1309-1315.

9. Kim MK, Zhao C, Kim SD, Kim DG, Park JK. Relationship of sex hormones and nocturia in lower urinary tract symptoms induced by benign prostatic hyperplasia. Aging Male. 2012;15(2):90-95.

10. Liao CH, Chiang HS, Yu HJ. Serum testosterone levels significantly correlate with nocturia in men aged 40-79 years. Urology. 2011;78(3): 631-635.

11. Rył A, Rotter I, Miazgowski T, et al. Metabolic syndrome and benign prostatic hyperplasia: association or coincidence? Diabetol Metab Syndr. 2015;7:94.
12. Rył A, Rotter I, Słojewski M, et al. Can metabolic disorders in aging men contribute to prostatic hyperplasia eligible for transurethral resection of the prostate (TURP)? Inter J Environ Res Public Health. 2015;12(3):3327-3342.

13. Zhang X, Zeng X, Liu Y, Dong L, Zhao X, Qu X. Impact of metabolic syndrome on benign prostatic hyperplasia in elderly Chinese men. Urol Int. 2014;93(2):214-219.

14. Ozden C, Ozdal OL, Urgancioglu G, Koyuncu H, Gokkaya S, Memis A. The correlation between metabolic syndrome and prostatic growth in patients with benign prostatic hyperplasia. Eur Urol. 2007;51(1):1 99-203; discussion 204-206.

15. Raheem OA, Parsons JK. Associations of obesity, physical activity and diet with benign prostatic hyperplasia and lower urinary tract symptoms. Curr Opin Urol. 2014;24(1):10-14.

16. Dorobek W, Krzeski T, Borkowski A, Zgliczyński S, Baranowska B. The evaluation of the contents of $\mathrm{lh}$ and $\mathrm{fsh}$ in the tissue of the prostatic adenoma. Urol Pol. 1988;41:1.

17. Pejčić T, Tosti T, Tešić Ž, et al. Testosterone and dihydrotestosterone levels in the transition zone correlate with prostate volume. Prostate. 2017;77(10):1082-1092.

18. van der Sluis TM, Meuleman EJ, van Moorselaar RJ, et al. Intraprostatic testosterone and dihydrotestosterone. Part II: concentrations after androgen hormonal manipulation in men with benign prostatic hyperplasia and prostate cancer. BJU Int. 2012;109(2):183-188.

19. Alberti KG, Zimmet P, Shaw J; IDF Epidemiology Task Force Consensus Group. The metabolic syndrome-a new worldwide definition. Lancet. 2005;366(9491):1059-1062.

20. Wesołowski P, Wańkowicz Z. [Insulin resistance diagnostic methods and clinical outcomes]. Nefrol Dial Pol. 2011;15:243-246. Polish [with English abstract].

21. Golds G, Houdek D, Arnason T. Male hypogonadism and osteoporosis: the effects, clinical consequences, and treatment of testosterone deficiency in bone health. Int J Endocrinol. 2017;2017:4602129.

22. Vignozzi L, Cellai I, Santi R, et al. Antiinflammatory effect of androgen receptor activation in human benign prostatic hyperplasia cells. J Endocrinol. 2012;214(1):31-43.

23. Kaplan SA, Lee JY, O’Neill EA, Meehan AG, Kusek JW. Prevalence of low testosterone and its relationship to body mass index in older men with lower urinary tract symptoms associated with benign prostatic hyperplasia. Aging Male. 2013;16(4):169-172.

24. Roehrborn CG. Benign prostatic hyperplasia: etiology, pathophysiology, epidemiology, and natural history. In: Wein AJ, Kavoussi LR, Partin AW, Peters CA, editors. Campbell-Walsh Urology. Philadelphia, PA: Elsevier; 2016:2425-2462.

25. van der Sluis TM, Vis AN, van Moorselaar RJ, et al. Intraprostatic testosterone and dihydrotestosterone. Part I: concentrations and methods of determination in men with benign prostatic hyperplasia and prostate cancer. BJU Int. 2012;109(2):176-182.

26. Parsons JK. Modifiable risk factors for benign prostatic hyperplasia and lower urinary tract symptoms: new approaches to old problems. J Urol. 2007;178(2):395-401.

27. Gacci M, Corona G, Vignozz L, et al. Metabolic syndrome and benign prostatic enlargement: a systematic review and meta-analysis. BJU Int. 2015;115(1):24-31.

28. Lee JH, Kwon H, Park YW. Association of lower urinary tract symptom/ benign prostatic hyperplasia measures with international index of erectile function 5 in middle-aged policemen of Korea and the role of metabolic syndrome and testosterone in their relationship. Urology. 2013;82(5):1008-1012.

29. Yassin AA, El-Sakka AI, Saad F, Gooren LJ. Lower urinary - tract symptoms and testosterone in elderly men. World J Urol. 2008;26(4): 359-364.

30. Kim WT, Yun SJ, Choi YD, et al. Prostate size correlates with fasting blood glucose in non-diabetic benign prostatic hyperplasia patients with normal testosterone levels. J Korean Med Sci. 2011;26(9): 1214-1218. 
31. Romero-Otero J, García B, Jiménez Alcalde E, García Cruz E, Leibar Tamayo A, Rodríguez Antolín A. [Patient with TDS and lower urinary tract symptoms (LUTS)]. Arch Esp Urol. 2013;66(7):657-662. Spanish [with English abstract].

32. Vignozzi L, Morelli A, Sarchielli E, et al. Testosterone protects from metabolic syndrome-associated prostate inflammation: an experimental study in rabbit. $J$ Endocrinol. 2012;212(1):71-84.

33. Antunes AA, Araújo LH, Nakano E, Muracca E, Srougi M. Obesity may influence the relationship between sex hormones and lower urinary tract symptoms. Int Braz J Urol. 2014;40(2):240-246.

34. Oszukowska E, Słowikowska-Hilczer J, Lipiński M, Kula K. Changes in estradiol and testosterone secretions in man with leydigioma and after removal of the tumour. Urol Pol. 2003;56:2.

35. Bélanger A, Candas B, Dupont A, et al. Changes in serum concentrations of conjugated and unconjugated steroids in 40- to 80-year-old men. J Clin Endocrinol Metab. 1994;79(4):1086-1090.

36. Bernoulli J, Yatkin E, Konkol Y, Talvitie EM, Santti R, Streng T. Prostatic inflammation and obstructive voiding in the adult Noble rat: impact of the testosterone to estradiol ratio in serum. Prostate. 2008; 68(12):1296-1306.

37. Tan MO, Karabiyik I, Uygur MC, Diker Y, Erol D. Serum concentrations of sex hormones in men with severe lower urinary tract symptoms and benign prostatic hyperplasia. Int Urol Nephrol. 2003;35(3):357-363.

38. Rajaram S, Baylink DJ, Mohan S. Insulin-like growth factor-binding proteins in serum and other biological fluids: regulation and functions. Endocr Rev. 1997;18(6):801-831.
39. Ryl A, Rotter I, Slojewski M, et al. Hormone concentration, metabolic disorders and immunoexpression of androgen and estrogen-alpha receptors in men with benign prostatic hyperplasia and testosterone deficiency syndrome. Folia Histochem Cytobiol. 2015;53(3):227-235.

40. Siejka A, Schally AV, Block NL, Barabutis N. Mechanisms of inhibition of human benign prostatic hyperplasia in vitro by the luteinizing hormone-releasing hormone antagonist cetrorelix. BJU Int. 2010;106(9): $1382-1388$.

41. Wang Z, Olumi AF. Diabetes, growth hormone-insulin-like growth factor pathways and association to benign prostatic hyperplasia. Differentiation. 2011;82(4-5):261-271.

42. Wadsworth TL, Carroll JM, Mallinson RA, Roberts CT Jr, Roselli CE. Saw palmetto extract suppresses insulin-like growth factor-I signaling and induces stress-activated protein kinase/c-Jun N-terminal kinase phosphorylation in human prostate epithelial cells. Endocrinology. 2004;145(7):3205-3214.

43. Gat Y, Gornish M. Reversal of benign prostate hyperplasia by superselective intraprostatic androgen deprivation therapy. Eur Urol Rev. 2009;4:10-14.

44. Gat Y, Gornish M, Heiblum M, Joshua S. Reversal of benign prostate hyperplasia by selective occlusion of impaired venous drainage in the male reproductive system: novel mechanism, new treatment. Andrologia. 2008;40(5):273-281.
Clinical Interventions in Aging

\section{Publish your work in this journal}

Clinical Interventions in Aging is an international, peer-reviewed journal focusing on evidence-based reports on the value or lack thereof of treatments intended to prevent or delay the onset of maladaptive correlates of aging in human beings. This journal is indexed on PubMed Central, MedLine,

\section{Dovepress}

CAS, Scopus and the Elsevier Bibliographic databases. The manuscript management system is completely online and includes a very quick and fair peer-review system, which is all easy to use. Visit http://www.dovepress. com/testimonials.php to read real quotes from published authors. 